\title{
Evaluation of Solid Waste Generation, Categories and Disposal Options in Developing Countries: A Case Study of Nigeria
}

\author{
1* BABAYEMI, J. O.; ${ }^{2}$ DAUDA, K. T. \\ ${ }_{1,2}$ Department of Chemical Sciences, Bells University of Technology, Km 8, Idiroko Road, Benja Village, P.M.B 1015, Ota, Ogun State, \\ Nigeria.E-mail: babayemola@yahoo.co.uk.Phone: +2348060709930
}

\begin{abstract}
The quantity and generation rate of solid wastes in Nigeria have increased at an alarming rate over the years with lack of efficient and modern technology for the management of the wastes. The generation rate, collection and disposal of solid wastes are functions of several factors which if well considered and appropriated could bring the desired solution to the waste management problems in Nigeria. The quantity and rate of solid waste generation in several cities in Nigeria, factors influencing the generation, solid waste types and categories, collection, disposal, reuse and recycling, and environmental problems were investigated in this study. The results indicated large generation at high rate without a corresponding efficient technology to manage the wastes. Of 201 respondents to questionnaire in Abeokuta, $35.8 \%$ used waste collection services, $64.2 \%$ used other waste disposal options, $16.4 \%$ used both, $68.7 \%$ and $58.7 \%$ were aware of waste collection service and waste management regulations, respectively; while $28.4 \%$ separated their solid wastes at source. @ JASEM
\end{abstract}

Solid wastes could be defined as non-liquid and nongaseous products of human activities, regarded as being useless. It could take the forms of refuse, garbage and sludge (Leton and Omotosho, 2004). Cities in Nigeria, being among the fast growing cities in the world (Onibokun and Kumuyi, 1996) are faced with the problem of solid waste generation. The implication is serious when a country is growing rapidly and the wastes are not efficiently managed. Waste generation scenario in Nigeria has been of great concern both globally and locally. Of the different categories of wastes being generated, solid wastes had posed a hydra-headed problem beyond the cope of various solid waste management systems in Nigeria (Geoffrey, 2005), as the streets experience continual presence of solid waste from commercial activities. Various researchers have undertaken to study solid waste generation pattern in Nigeria, but most of the studies are usually a case study of a particular state or locality in Nigeria; and it seems the awareness about solid waste generation in several other cities are obscured.

This paper attempts to expand the scope of knowledge of solid waste generation beyond a particular locality; and by reviewing the available literatures and analyzing the information, to create such awareness that those who are in the field of environmental management may put all hands on deck to rescue Nigeria from the menace of solid waste generation. The review is necessary to give policy makers and every sector involved in environmental management a better view of the state of solid waste generation in Nigeria. ). Ogbonna et al (2002) have observed that little or no attention is given to some traditional suburban settlements for provision of waste collection and disposal services. Abeokuta, a traditional city in Nigeria, now to be found on the lane of increasing population due to extraordinary increase in the number of higher institutions in the state and improving economy, is yet to be fully explored for adequate information and data on solid waste collection and disposal. Using the instrument of questionnaire, interview and personal observations, this study also seeks to evaluate the common solid waste disposal options, the level of awareness on waste management; the effect of gender, age and educational status on solid waste management and reasons for not using an appropriate waste collection service (WCS) in traditional cities in Nigeria, taking Abeokuta as a case study. Age, educational status, and amount charged for waste collection services had been identified as factors influencing solid waste management in highly populated cities like Ibadan and Lagos ( Ajani, 2007; Sridhar et al., 1985): do these factors influence waste management in 'just growing' cities like Abeokuta? Among others, this study seeks to answer this question. The knowledge of the current status of waste disposal options and level of awareness of solid waste management will help the government and sectors involved in waste management to take action to establish and reinforce appropriate waste collection and disposal option and environmental education and awareness on waste management.

\section{METHODOLOGY}

Extensive literature search, administering of questionnaire, interview and personal observation were employed. Questionnaires were administered, covering the major parts of Abeokuta: Panseke, Okeilewo, Ibara housing estate, Asero housing estate, Camp, Obantoko, Osiele, Lafenwa, Adatan, Olomore, Kuto, Onikolobo, Isale-igbehin, Olorunsogo, Ita-eko, Idi-aba, Carwash, Akomoje, Elega and several other parts of Abeokuta. 


\section{RESULTS AND DISCUSION Solid waste generation in Nigeria}

The quantity and rate of solid waste generation in the various states of Nigeria depends on the population, level of industrialization, socio-economic status of the citizens and the kinds of commercial activities being predominant. Nigeria, having a population of 120 millions (Sridhar and Adeoye, 2003), generated $0.58 \mathrm{Kg}$ solid waste per person per day, and in some Nigerian cities as follows: Abeokuta in Ogun state $(0.60 \mathrm{Kg} /$ person/day), Ado-Ekiti in Ekiti state $(0.71 \mathrm{Kg} / \mathrm{person} /$ day $)$, Akure in Ondo state $(0.54 \mathrm{Kg} /$ person /day), Ile-Ife in Osun state $(0.46 \mathrm{Kg} / \mathrm{person} /$ day $)$ and Ibadan in Oyo state $(0.71 \mathrm{Kg} / \mathrm{person} /$ day) (Adewumi et al., 2005). About $55200 \mathrm{Kg}$ per day of solid wastes were estimated to be generated in the traditional city of Oyo in Oyo state (Abel and Afolabi, 2007). Another source (GEO-2000), considering the population of Lagos to be10.3 millions, reports the solid waste generation of 3.7 million tones per year for Lagos in 1990, and $401 \mathrm{Kg} / \mathrm{capita} /$ year for Ibadan in 1997 . Considering the population of Kano to be 1.4 million, Lewcock (1994) gave an estimate of total solid waste generated in the city as $450 \mathrm{t}$ per day. The per capita solid waste generation in Ilorin, the capital city of Kwara state, was projected to be $0.43 \mathrm{Kg} /$ person/day by the year 2 020 (Yusuf and Oyewumi, 2008). As reported by Oluwemimo (2007), tones per year of solid waste generation in Kaduna, Onitsha, Aba, New Bussa and Uyo were estimated to be 4313 124, 386 593, 236 703, 9518 and 20923 respectively. Report on solid waste generation in Maiduguri in Borno state, showed an estimate of 8.5 million tones for the year 2002 (Dauda and Osita, 2003). A study conducted on solid waste generation in Port Harcourt in River state, and Warri in Delta state, showed an estimate of 164 029t/year and 66 721t/year, respectively (Ajao and Anurigwo, 2002). Makurdi, an urban city in Benue state, generated a household solid waste of $0.54 \mathrm{Kg} / \mathrm{capita} /$ day (Sha'Ato et al., 2006). Aziegbe (2007) recorded high generation of all sorts of polyethylene packaging materials in Benin. Between $0.55 \mathrm{Kg}$ and $0.58 \mathrm{Kg}$ of solid waste per person per day was generated in Abuja (Imam et al., 2007).

\section{Solid waste disposal and waste management awareness in Abeokuta}

Generally, there were six major dumpsites, each located in Abeokuta, Agbara, Ota, Sagamu, Ijebu-ode and Ago-Iwoye. There were both public and a number of private waste collection services. The private waste collectors charge between 500 and 1000 naira per drum. There were plans going on and proposals being made on integrated waste management. There were 201 respondents to the questionnaire. The respondents consisted of male and female with various age, occupational and educational status. As shown in Table 1, Awareness of waste collection service (WCS) was highest among the groups with age greater than 30, followed by those between 20 and 30, while it was least among those less than 20 years of age. The same pattern could be observed for awareness of waste management regulations (WMR). The percentage of those who used WCS was highest among those greater than 30 years of age while the percentage of those who used other indiscriminate WDO was higher among those between 20 and 30 years and highest among those who were less than 20 years of age. The influence of age on solid waste management could then be inferred.

Table 2 shows the overall percentages of those who used WCS, other WDO, both WCS and other WDO and reasons for not using WCS. Those who used other WDO like open dumping, open burning, dumping in drainages and burying had the highest percentage $(64.2 \%)$. Those who did not use WCS gave the strongest reason $(49.8 \%)$ of being not available in their street or area of residence. The relationships between educational status, awareness of WCS and WMR, and other WDO are shown in Table 3. The awareness of WMR was highest among those who had tertiary education and least among those who had primary education. The percentages of those who used WCS seemed not to be influenced by educational status as the results did not follow an orderly pattern; the reasons could be the availability, cost and effectiveness of WCS as seen in Table 2. As could be seen in Table 4, the results infer gender influence on waste management: the percentages of those who were aware of WCS and WMR, separated waste at source and also involved in open burning were higher among females, while the percentages of those involved in open dumping, dumping in drainages and burying were higher among males.

Table 1: Age, awareness, waste separation and disposal options.

\begin{tabular}{llll}
\hline & \multicolumn{3}{c}{ Age range } \\
\hline & Less than 20 & $20-30$ & Above 30 \\
Aware of WCS (\%) & 64.0 & 66.7 & 100.0 \\
Aware of WCR (\%) & 56.0 & 60.0 & 66.7 \\
Use of WCS (\%) & 33.3 & 28.9 & 88.9 \\
Other WDO (\%) & 63.3 & 64.4 & 11.1 \\
\hline Separate the waste at source (\%) & 32.7 & 20.0 & 11.1 \\
\hline
\end{tabular}

* Corresponding author: Babayemi, J. O. 
Table 2. Use of WCS, other WDO, both WCS and other WDO and reasons for not using WCS:

\begin{tabular}{cc}
\hline & Percentage \\
\hline Use of WCS & 35.8 \\
Other WDO & 64.2 \\
Both WCS and WDO & 16.4 \\
Reasons for using other WDO: & 6.5 \\
(a) Not effective in my area & 49.8 \\
\hline (b) Not available in my area & 3.5 \\
\hline (c) Too costly & \\
\hline
\end{tabular}

Table 3. Educational level, awareness and waste disposal options.

\begin{tabular}{cccc}
\hline & Primary & Secondary & Tertiary \\
\hline Aware of WMR (\%) & 40.0 & 54.1 & 65.0 \\
Aware of WCS (\%) & 40.0 & 29.4 & 40.0 \\
\hline Other WDO (\%) & 60.0 & 70.6 & 60.0 \\
\hline
\end{tabular}

Table 4. Gender, awareness of WCS and WMR, separation of waste at source and the use of various WDO.

\begin{tabular}{cccc}
\hline & Male & Female & Total \\
\hline Aware of WCS (\%) & 25.9 & 42.8 & 68.7 \\
Aware of WMR (\%) & 21.9 & 36.8 & 58.7 \\
Separate the waste at source (\%) & 9.5 & 18.9 & 28.4 \\
Open burning (\%) & 18.4 & 35.8 & 54.2 \\
Open dumping (\%) & 12.4 & 9.0 & 21.4 \\
Dumping in water ways (\%) & 1.0 & 0.5 & 1.5 \\
\hline Burying (\%) & 3.0 & 0.5 & 3.5 \\
\hline
\end{tabular}

\section{Source, category and types}

Sources of solid waste generation in Nigeria among others are commercial, industrial, household, agricultural and educational establishments. The solid waste types include paper, nylon, wood, dust, cloth, metal scraps, electronic gadgets, bottles, food remnants and vegetables; saw dust, ashes, rubber, bones and plastics. Of total solid waste generated in Ibadan, $66.1 \%$ are domestic, $20.3 \%$ commercial and $11.4 \%$ industrial (Adewumi et al., 2005). Average medical solid waste generation in Lagos lies between $0.562 \mathrm{Kg} / \mathrm{bed} /$ day and $0.670 \mathrm{Kg} / \mathrm{bed} /$ day (Longe and Williams, 2006). In Abuja, the Federal Capital Territory, medical solid waste of $2.78 \mathrm{Kg} / \mathrm{bed} /$ day was generated (Bassey et al., 2006), and in Ibadan, $150 \mathrm{~g} / \mathrm{head} /$ day (Coker et al., 1999). Several thousands used computers are imported to Nigeria through Lagos seaport monthly and many of them lose the desired value within a short time, ending up to build the e-waste pile in Nigeria (Ukem, 2008).

\section{Factors affecting solid waste generation}

Several factors influence the solid waste generation in Nigeria. Lack of advanced technology, facility for separation at source, strength of solid waste management policy and enforcement, environmental education and awareness and income status of individuals among others, are factors affecting solid waste scenario in Nigeria. Abel (2009) showed that education, income and social status are important factors influencing per capita solid waste generation in Ogbomoso, Oyo state. Age, location, occupation and amount charged for waste collection are determinant factors for using public waste collection services in Ibadan (Ajani, 2007). The quantity and categories of solid waste generation also varies with socio-economic groups in which the high and middle groups take the lion share (Sridhar et al., 1985).

\section{Reuse and recycling}

There has been an emergence of biodegradable solid waste in the production of organic fertilizer and possible use in the production of biogas. Some researchers have studied the great potentials in Nigeria's municipal solid wastes to produce enormous amount of methane gas (Yusuf and Oyewumi, 2008). Mixtures of manure and ashes from burning of urban solid wastes have been used for soil amelioration to boost agricultural productions in Jos (Pasquini and Alexander, 2003). Abeokuta alone generates $2288 \mathrm{~m}^{3}$ of wood wastes per day from saw mills activities (Aina, 2006).If each state in Nigeria generates equal amount of wood wastes, then 82368 $\mathrm{m}^{3}$ of wood wastes will be generated in the country per day, and $30064320 \mathrm{~m}^{3}$ annually. Resource from wood wastes alone could meet more than Nigeria's needs in the wood-based raw materials for such industries as potash industry, since African wood species have been studied to have potentials for

\footnotetext{
* Corresponding author: Babayemi, J. O.
} 
generating good amount of potash (Adewuyi et al., 2008).

\section{Solid waste collection}

Several states in the country are coming up with various means of waste collection initiated by both public and private sectors, although the effectiveness of this is largely a function of location; and where the collection is done by private sectors, it is a function of income of the owner of the waste to be able to pay the amount charged. Agunwamba et al (1998) reported several systems of solid waste collection in Onitsha, though modern solid waste management systems were still solicited for.

\section{Solid waste disposal}

Open dump of solid waste is a common practice in Nigeria. While some employ the service of streams to transport their solid wastes out of their sight, some directly dump their solid wastes by the road sides. In some part of Nigeria, refuse is generally buried, though some heedless burning is sometimes observed (Igoni, et al., 2007). Several Nigerians have considered it a cheap way of disposing off their solid wastes by setting the mixed wastes on fire in a little corner in their backyard or in a very open place. Even, mountains of mixed solid wastes in so-called designated places are set on fire, causing serious and dangerous environmental pollution. Some thick and dark smokes from burning of plastic components of electronics have been seen spiraling up the sky in computer villages. Saw millers set the mountain of wood wastes on fire, while awaiting heavy rains to transport the ashes away.

\section{Environmental problems}

Folorunso and Awosika (2001) related flooding in Lagos to clogging of drainage channels by dumped solid wastes. There is abundant release of gaseous toxic substances into Nigerian environment as well as jeopardizing of health of scavengers as a result of burning of obsolete e-wastes. Due to contact with smokes from burning of solid wastes and gaseous emission from dumpsites, cases of several diseases have been recorded (Oyelola et al., 2009).

\section{Solid waste management}

Solid waste management in Southwest Nigeria suffers set back due to unwholesome waste disposal habits of the citizens as well as funding and sanitation laws enforcement impotency (Sangodoyin, 1993). Solid waste collection and disposal in a developing country like Nigeria have become an integral and indispensable urban service.
Conclusion: Though the level of awareness of waste collection services and waste management regulations were relatively high in Abeokuta, the percentage of those who used other indiscriminate solid waste disposal methods like open dumping, open burning, and dumping in drainages was higher. Educational status, age, gender, cost of waste collection services and the location of residence, among others, were factors influencing solid waste management in Abeokuta. The quantity and the rate of solid wastes generation in Nigeria have outgrown the capacity of nature to naturally absorb them. Individual in the country has a part to play. Nigeria has a long way to go in the area of environmental education and awareness for the citizens to put off the long-acquired habit of indiscriminate waste disposal and hunt for second-hand electronic gadgets which has made Nigeria a victim of dumping ground for electronic wastes. There is the need to enlighten the populace on the wealth inherent in their organic, plastic and paper wastes. Solid waste management policies and enforcement of sanitation laws in various Nigerian states should be energized, and various environmental organizations and societies to do more until the dreamed clean environment in Nigeria becomes a reality. Efforts of environmental scientists in the country are highly solicited in researching into all possibilities of making sustainable solid waste management to stay in Nigeria. Government should reinforce waste collection and disposal systems in every state while strengthening and enforcing the appropriate laws. To prevent serious environmental disaster in Nigeria, priority should be given to waste management.

\section{REFERENCES}

Abel, OA (2009). An analysis of solid waste generation in a traditional African city: the example of Ogbomoso, Nigeria. Environment and Urbanization, SAGE Journals, 19(2): 527537.

Abel, OA; Afolabi, O (2007). Estimating the quantity of solid waste generation in Oyo, Nigeria. Waste Management and Research, SAGE Journals, 25(4): 371-379.

Adewumi, IK; Ogedengbe, MO; Adepetu, JA; Fabiyi, YL (2005). Planning organic fertilizer industries for municipal solid wastes management. Journal of Applied Sciences Research, 1(3): 285-291.

Adewuyi, GO; Obi-Egbedi, NO; Babayemi, JO (2008). Evaluation of ten different African wood species for potash production. International Journal of Physical Science, 3(3): 63-68. 
Agunwamba, JC; Ukpai, OK; Onyebuenyi, IC (1998). Solid waste management in Onitsha, Nigeria. Waste Managent and Research, 16(1): 23-31.

Aina, OM (2006). Wood waste utilization for energy generation. Proceedings of the International Conference on Renewable Energy for Developing Countries, 2006.

Ajani, OIY (2007). Determinants of an effective solid waste management in Ibadan Metropolis, Oyo state, Nigeria. Journal of Food, Agriculture and Environment, 6(1): 152-157.

Ajao, EA; Anurigwo, S (2002). Land-based sources of pollution in the Niger Delta, Nigeria. AMBIO: A Journal of the Human Environment, 31(5): 442-445.

Aziegbe, FI (2007). Seasonality and environmental impact status of polyethylene (cellophane) generation and disposal in Benin city, Nigeria. J. Hum. Ecol. 22(2): 141-147.

Bassey, BE; Benka, MO; Aluyi, HSA (2006). Characterization and management of solid medical wastes in the Federal Capital Territory, Abuja, Nigeria. African Health Sciences 6(1): 58-63.

Coker, AO; Sikiru, KA; Sridhar, MKC; Sangodoyin, AY (1999). Characterization and management of solid hospital wastes. Integrated Development for Water Supply and Sanitation, 25 ${ }^{\text {th }}$ WEDC Conference, Addis Ababa, Ethiopia.

Dauda, M; Osita, O O (2003). Solid waste management and re-use in Maiduguri, Nigeria. Towards the Millenium Development Goals. 29 WEDC International Conference, Abuja, Nigeria, pp. 20-23.

Folorunso, R; Awosika, L (2001). Flood mitigation in Lagos Nigeria through the wise management of solid waste: the case of Ikoyi and Victoria Islands. Managing Conflicts Over Resources and Values. Results of a workshop on 'Wise practices for coastal conflict preventionand resolution', Maputo, Mozambique, 19-23 November 2001.

Geoffrey, IN (2005). The urban informal sector in Nigeria: towards economic development, environmental health, and social harmony.Global Urban Development Magazine 1(1).
Global Environmental Outlook (GEO) (2000). Urban Areas. The State of the Environment - Africa.

Igoni, AH; Ayotamuno, MJ; Ogaji, SOT; Probert, SD (2007). Municipal solid waste in Port Harcourt, Nigeria. Applied Energy, Elsevier 84(6): 664-670.

Imam, A; Mohammed, B; Wilson, DC; Cheeseman, CR (2008). Solid waste management in Abuja, Nigeria. Waste Management 28(2): 468-472.

Leton, TG; Omotosho, O (2004). Landfill operations in the Niger delta region of Nigeria. Engineering Geology 73(1-2): 171-177.

Lewcock, CP (1994). Case study of the use of urban waste by near-urban farmers of Kano, Nigeria. 23 January- March 7, 1994. Visit Report. Project no. A0354 for Natural Resources Institute, Ghatham, U.K. 69pp.

Longe, E.O. and Williams, A. (2006). A preliminary study of medical waste management in Lagos metropolis, Nigeria. Iranian Journal of Environmental Health, Science and Engineering 3(2):133-139.

Okunola, SO; Amao, JO; Olarinde, LO (2005). An analysis of agricultural solid waste management and its effect on government spending in Ibadan metropolis of Oyo state, Nigeria. Journal of Environmental Extension, 5: 11-17.

Oluwemimo, O (2007). Social systems, institutions and structures: urbanization, poverty and changing quality of life. Paper presented at the training session of the foundation for environmental development and education in Nigeria, Thursday, February 22, 2007.

Onibokun, AG; Kumuyi, AJ (1996).Urban poverty in Nigeria: towards sustainable strategies for its alleviation. Centre for African Settlement Studies and Development, Ibadan, Nigeria. CASSAD Monograph Series 10. pp. 1-2.

Oyelola, OT; Babatunde, AI; Odunlade, AK (2009). Health implications of solid waste disposal: case study of Olusosun dumpsite, Lagos, Nigeria. International Journal of Pure and Applied Sciences 3(2).

Pasquini, MW; Alexander, MJ (2004). Chemical properties of urban waste ash produced by open burning on the Jos plateau: implications for agriculture. Science of the Total Environment 319(1-3): 225-240. 
Sangodoyin, AY (1993). Domestic waste disposal in southwest Nigeria. Environmental Management and Health 4(3): 20-23.

Sha'Ato, R; Aboho, SY; Oketunde, FO; Eneji, IS; Unazi, G; Agwa, S (2006). Survey of solid waste generation and composition in a rapidly growing urban area in central Nigeria. Waste Management 27(3): 352-358.

Sridhar, MKC; Adeoye, GO (2003). Organo-mineral fertilizer from urban wastes: development in Nigeria. The Nigerian Field, 68: 91-111.
Sridhar, MKC; Bammeke, AO; Omisakin, MA (1985). A study on the characteristics of refuse in Ibadan, Nigeria. Waste Management and research 3(3): 191-201.

Ukem, EO (2008). Electroni waste: a growing challenge in Nigeria. Global Journal of Pure and Applied Sciences 14(4): 459-462.

Yusuf, RO; Oyewumi, MO (2008). Qualitative assessment of methane generation potential for municipal solid wastes: a case study. Environmental Research Journal, Medwell Journals 2(4): 138-144. 